\title{
Konsep Tafakur untuk Penguatan Efikasi Diri pada Pribadi Introvert
}

\author{
Nining Mirsanti \\ UIN Sunan Kalijaga Yogyakarta
}

Naskah diterima 17 Mar 2019, direvisi 30 Apr 2019, disetujui 2 Jul 2019

\begin{abstract}
Since man was born he has been given various natural potentials or in Islam called fitrah. The task of man is to develop that nature so that it runs according to its nature. In reality it can be found various individuals with a degree of difficulty to develop their nature, such as introverted individuals, one of the causes of which is low self-efficacy. Therefore, the concept of tafakur is needed. The type of research used in this article is library research and the nature of this research is qualitative descriptive. The concept of tafakur is present to direct individuals to Islamic concepts to see that all the realities of their lives are optimistically good that the process of adjusting themselves to the environment will be even better, because tafakur is an activity carried out by humans to present the world as a model and effectively treat it according to its purpose and how to deal with a problem by taking lessons behind the problem at hand, so that it does not cause conflict or conflict in itself which is understood as intrapersonal communication by understanding and providing solutions to itself that there are still many shortcomings in the individual, so the concept of tafakur will very useful for improving introverted personal self-efficacy.
\end{abstract}

Keywords:Tafakur, Self-Efficacy, Introvert.

Abstrak Semenjak manusia dilahirkan ia telah dibekali berbagai potensi alami atau dalam Islam disebut fitrah. Tugas manusia adalah mengembangkan fitrah tersebut supaya berjalan sesuai kodratnya.Dalam realitas dapat ditemukan bermacam-macam individu dengan tingkat kesulitannya untuk mengembangkan fitrahnya, seperti individu introvert yang salah satu penyebabnya adalah rendahnya efikasi diri. Oleh karena itu, diperlukannya konsep tafakur.Jenis penelitian yang digunakan dalam artikel ini adalah library research (penelitian pustaka) 
dan sifat penelitian ini adalah deskriptif kualitatif.Konsep tafakur hadir untuk mengarahkan individu kepada konsep Islami untuk melihat segala realitas kehidupannya optimis baik itu proses penyesuaian dirinya dengan lingkungan akan lebih baik lagi, karena tafakur adalah suatu kegiatan yang dilakukan oleh manusia untuk mempresentasikan dunia sebagai model dan memberikan perlakuan terhadapnya secara efektif sesuai dengan tujuan dan cara menghadapi suatu masalah dengan mengambil hikmah dibalik masalah yang dihadapi, sehingga tidak menimbulkan konflik atau pertentangan dalam dirinya yang pahami sebagai komunikasi intrapersonal dengan memahami dan memberikan solusi terhadap dirinya bahwa masih banyak kekurangankekurangan yang ada pada diri individu tersebut, sehingga konseptafakur akan sangat berguna untuk meningkatkan efikasi diri pribadi introvert.

Kata Kunci:Tafakur, Efikasi Diri, Introvert.

\section{A. PENDAHULUAN}

Proses kehidupan manusia dari waktu ke waktu tidak dapat dipungkiri bahwa di dalam kehidupan manusia tidak akan pernah terlepas dengan masalah. Bahkan disetiap tahap perkembanganakan selalu muncul masalah. Oleh karena itu, manusia dituntut harus mampu melewati tugas-tugas perkembangan dengan baik agar memperoleh kehidupan yang memadai. Semenjak manusia dilahirkan ia telah dibekali berbagai potensi alami atau dalam Islam disebut fitrah. Tugas manusia adalah mengembangkan fitrah tersebut supaya berjalan sesuai kodratnya (M. Carlos, 2006: 198).Dalam realitas dapat ditemukan bermacam-macam individu dengan tingkat kesulitannya untuk mengembangkan fitrahnya oleh pembimbing maupun konselor salah satunya individu introvert.

Seseorang yang memliki pribadi yang introvert lebih sulit untuk melakukan komunikasi dengan banyak orang. Di sisi lain, 
fitrah seorang manusia adalah sebagai makhluk sosial yaitu menuntut kita untuk selalu bisa berkomunikasi dengan manusia di sekeliling kita. Menurut Carl Gustav Jung, orang-orang introvert itu mereka yang terampil dalam melakukan perjalanan ke dunia dalam, yaitu diri mereka sendiri. Mereka selalu mencoba memahami diri mereka sendiri dengan melakukan banyak perenungan dan berkontemplasi. Pada akhirnya, mereka menjadi orang yang memahami dirinya sendiri, pendirian keras, tidak mudah terpengaruh oleh orang lain, dan mengetahui apa yang menjadi tujuan dalam hidupnya. Dan orang introvert adalah orang yang lebih cenderung kepada menyendiri dan menyimpan perasaan. Dengan demikian, pribadi introvert akan berpengaruh penyesuaian diri yang kurang baik terhadap dirinya dan lingkungannya.

Demikian pula karakteristik yang harus dimiliki oleh seseorang yang beriman kepada Allah dalam kaitannya dengan melakukan penyesuaian dirinya adalah kemampuan melihat tanda-tanda kekuasaan Allah melalui makhluk-Nya atau mampu bertafakur.

Tafakur merupakan komponen penting yang harus dimiliki bagi setiap orang beriman, karena tafakur merupakan cerminan seorang mukmin.Ia dapat melihat segala kebaikan dan keburukan melaluinya. Demikian penjelasan Al-Hasan. Dengan tafakur maka seorang mukmin akan mengetahui hakikat dan rahasia makhluk ciptaan-Nya atau suatu peristiwa yang terjadi disekitarnya.

Akal yang dimiliki oleh manusia tentu menjadi bekal utama untuk menjalani kehidupan di muka bumi ini, dalam proses melakukan penyesuaian diri maka bertafakkur itu sangat diperlukan sebab seseorang akan berhadapan dengan lingkungannya atau orang lain sehingga akan membantu seseorang dalam memahami akan kebersamaan dalam kehidupan di dunia ini sebagai makhluk sosial yang diciptakan oleh Allah Swt.

Berdasarkan pemaparan di atas peningkatan efikasi diri pada pribadi introvert perlu dilakukan melalui konsep tafakursebagai 
bekal dalam pribadi yang sehat untuk mencapai kebahagiaan hidup di lingkungan sekitarnya.

\section{B. PEMBAHASAN}

Konsep efikasi diri (self-efficacy) pertama kali dikemukakan oleh Albert Bandura.Bandura, mendefinisikan efikasi diri sebagai keyakinan seseorang terhadap kemampuannya untuk mengorganisasikan dan melaksanakan serangkaian tindakan yang dibutuhkan untuk mencapai tujuan yang dikehendaki(Albert Bandura, 3). Efikasi diri dikaitkan dengan cara mengorganisasikan dengan baik dan menentukan tindakan yang dimaksud dengan situasi yang mungkin terjadi (B. Smet, 1994: 191).Efikasi diri menurut Ogden adalah persamaan individu tentang persamaan dirinya, seberapa jauh merasa mampu menampilkan perilakuperilaku yang di harapkan (J. Ogden, 2000: 201). Menurut Baron dan Byrne, Efikasi diri adalah evaluasi seseorang terhadap kemampuan atau kompetensinya untuk melakukan sebuah tugas, mencapai tujuan atau mengatasi hambatan. Evaluasi ini dapat bervariasi tergantung pada situasi (R.A Baron, 1997: 183).

Berdasarkan uraian di atas, maka dapat disimpulkan bahwa efikasi dirimerupakan keyakinan yang melekat pada seseorang terhadap kemampuan atau potensi yang dimilikinya untuk membentuk perilaku yang relevan pada tugas atau situasi khusus, yang dibentuk dari cara pandang atau cara berfikir terhadap suatu peristiwa.

Bandura menjelaskan bahwa efikasi diri terdiri dari beberapa aspek.Pertama, level (tingkat kesulitan) yaitu kemampuan seseorang dalam menyelesaikan tugas itu berbeda sesuai tingkat kesulitan masalah. Individu dengan efikasi diri tinggi akan mempunyai keyakinan yang tinggi tentang kemampuan dalam melakukan suatu tugas, dan sebaliknya. Kedua, generality (keluasan), cakupan bidang tingkah laku manusia itu luas dimana individu merasa yakin terhadap kemampuannya.Individu mampu menilai keyakinan dirinya dalam menyelesaikan tugas di banyak bidang atau dalam bidang tertentu saja.Mampu atau tidaknya 
individu mengerjakan bidang-bidang dan konteks tertentu mengungkapkan gambaran secara umum tentang efikasi diri individu tersebut.Ketiga, strength (ketahanan), hal yang berkaian dengan kekuatan pada keyakinan individu atas kemampuannya. Individu mempunyai keyakinan yang kuat dan ketekunan dalam usaha yang akan dicapai meskipun terdapat kesulitan dan rintangan. Dengan efikasi diri, kekuatan untuk usaha yang lebih besar mampu didapat.Semakin kuat perasaan efikasi diri dan semakin besar ketekunan, semakin tinggi kemungkinan kegiatan yang dipilih dan dilakukan menjadi berhasil.

Berdasarkan uraian di atas, dapat disimpulkan bahwa efikasi diri terdiri dari tiga aspek, yaitu level (tingkatan kesulitan), generality (keluasan) dan strength (ketahanan).Seseorang dikatakan mempunyai efikasi diri, jika di hadapkan pada tiga aspek di atas.

Adapunfaktor penting dalam membentuk efikasi diri yaitu:

- Mastery experience,pengalaman menyelesaikan masalah adalah sumber yang paling penting mempengaruhi efikasi diri seseorang, karena mastery experience memberikan bukti yang paling akurat dari tindakan apa saja yang diambil untukmeraih suatu keberhasilan atau kesuksesan, dan keberhasilan tersebut dibangun dari kepercayaan yang kuat didalam keyakinan individu. Kegagalan dan rintangan mengajarkan manusia bahwa kesuksesan membutuhkan kerja keras, setelah individu diyakinkan bahwa individu tersebut memilki hal-hal yang diperlukan untuk mencapai kesuksesan, individu akan berusaha untuk bangkit dan keluar dari kegagalan.

- Vicarious experience, pengalaman orang lainadalah pengalaman pengganti yang disediakan untuk model sosial. Mengamati perilaku dan pengalaman orang lain sebagai proses belajar individu. Melalui model ini efikasi diri individu dapat meningkat, terutama apabila individu merasa memiliki kemampuan yang setara atau bahkan merasa lebih baik daripada orang yang menjadi subjek belajarnya. 
- Verbal persuasion mempunyai pengaruh yang kuat pada peningkatan efikasi diri individu dan menunjukkan perilaku yang digunakan secara efektif. Seseorang yang dikenai persuasi verbal bahwa dirinya memiliki kemampuan untuk menyelesaikan tugas yang telah diberikan, maka orang tersebut akan menggerakkan usaha yang lebih besar dan akan meneruskan penyelesaian tugas tersebut.

- Kondisi fisiologis dan emosional, situasi yang menekan kondisi emosional dapat mempengaruhi efikasi diri. Gejolak emosi, goncangan, kegelisahan yang mendalam dan keadaan fisiologis yang lemah yang dialami individu akan dirasakan sebagai isyarat akan terjadi peristiwa yang tidak diinginkan, maka situasi yang menekan dan mengancam akan cenderung dihindari. Penilaian seseorang terhadap efikasi diri dipengaruhi oleh suasana hati. Suasana hati yang positif akan meningkatkan efikasi diri, sedangkan suasana hati yang negatif akan melemahkan efikasi diri.

Pendapat senada dikemukakan oleh Alwisol, efikasi diri atau keyakinan diri itu dapat diperoleh, diubah, ditingkatkan atau diturunkaan melalui salah satu atau kombinasi empat sumber, yaitu:

- Pengalaman performansiadalah prestasi yang pernah dicapai pada masa lalu. Sebagai sumber performansi masa lalu menjadi pengubah efikasi diri yang paling kuat pengaruhnya. Prestasi (masa lalu) yang bagus meningkatkan ekspektasi efikasi, sedangkan kegagalan akan menurunkan efikasi.

- Pengalaman vikariusdiperoleh melalui model sosial. Efikasi akan meningkat ketika mengamati keberhasilan orang lain, dan sebaliknya.

- Persuasi social, dampak dari sumber ini terbatas, tetapi pada kondisi yang tepat persuasi dari orang lain dapat mempengaruhi efikasi diri. Kondisi ini adalah rasa percaya kepada pemberi persuasi, dan sifat realistic dari apa yang dipersuasikan. 
- Keadaan emosi yang mengikuti suatu kegiatan akan mempengaruhi efikasi di bidang kegiatan itu, emosi yang kuat, takut, cemas, stress, dapat mengurangi efikasi diri. Bisa jadi, peningkatan emosi yang tidak berlebihan dapat meningkatkan efikasi diri (Alwisol, 2012: 361).

Berdasarkan uraian di atas, peneliti menyimpulkan bahwa sumber-sumber yang mempengaruhi efikasi diri terdiri dari empat faktor utama yaitu: mastery experience,vicarious experience, verbal persuasion, kondisi fisiologis dan emosional. Efikasi diri seseorang dapat ditingkatkan atau menurun tergantung dari empat faktor tersebut. Keempat faktor tersebut yang nantinya digunakan untuk acuan di dalam peningkatan efikasi diri.Bandura menyebutkan empat proses yang mengiringi efikasi diri, termasuk efikasi diri akademik, yaitu proses kognitif, motivasi, afeksi, dan seleksi.

Efikasi diri sangat diperlukan dalam interaksi sosial dan bimbingan sosial yang membahas tentang kepribadian seseorang, terkhusus kepribadian yang introvert. Menurut Allport, kepribadian merupakan suatu organisasi psychophysis yang dinamisdari seseorang yang menyebabkan ia dapat menyesuaikan diri dengan lingkungannya (Sujanto, 63). Menurut Heerdjankepribadian merupakan perpaduan antara keseluruhan pembawaan dengan pengaruh lingkungan.Kepribadian bertumbuh dan berkembang terus sepanjang hidup. Suatu perumpamaan yang dapat dipakai adalah kalau tubuh kita diibaratkan sebuah kendaraan bermotor, maka kepribadian adalah pengemudinya, pengemudi itu akan berubah sesuai dengan perubahan umur dan pengalaman hidup, begitu juga dengan kepribadian (Heerdjan, S., 1987: 51). Selanjutnya membahas tentang introvert, Jung dalam Budiraharjo menjelaskan bahwa individu yang memiliki tipe kepribadian introvert digambarkan sebagai individu yang ragu-ragu, reflektif, defensif, dan senang bersembunyi di balik rasa ketidakpercayaan (Budiraharjo, P., 1997: 67). Pribadi introvert akan mengalami gangguan atau hambatan dalam komunikasi interpersonal. 
Individu dengan karakteristik introvert suka menyendiri dan seringkali mengabaikan faktor eksternal yang penting (Keating, J.C., 1987: 30.

Introvert tidak mudah mengekspresikan dan menyatakan pikiran dan perasaannya di media sosial. Menurut Jung menyatakan bahwa pribadi introvert adalah seseorang yang lebih mementingkan dunia internal, pikiran, perasaan, fantasi dan mimpinya yang terbentuk pada dirinya sendiri. Menurut Jung pada jurnal riset mahasiswa ini menyatakan bahwa individu yang tertutup, suka menyendiri, tidak mudah membuka informasi pribadinya, menarik diri dari lingkungan, dan pendiam cenderung dalam tipe kepribadian introvert dan ada tipe kepribadian introvert yaitu cenderung menarik diri dan tenggelam dalam pengalaman-pengalaman batinnya sendiri.

Hadi Prayitno menyatakan pribadi introvert memiliki ciri ketika dalam menghadapi sesuatu banyak dipengaruhi oleh faktor subyektif yang berasal dari dunia batin sendiri, sebaliknya pribadi ekstrovert memiliki ciri lebih terbuka dan lebih dapat bersosialisasi sedangkan Zubaidah mengatakan perbedaan kedua kepribadian tersebut berpengaruh pula dengan kemampuan berkomunikasi dan bersosialisasi (Siswoto Hadi Prayitno, 2018).

Dapat disimpulkan bahwa introvert merupakan gangguan atau hambatan dalam komunikasi interpersonal, memiliki ciri organisasi kognitif yang tertutup oleh kepercayaan dan ketidakpercayaan tentang realitas serta tertutup, merasa sendiri, sensitif, penyesuaian dengan dunia di luar dirinya kurang baik, sukar bergaul dan kurang dapat menarik hati orang lain. Dan kepribadian introvert digambarkan sebagai individu yang raguragu, reflektif, defensif, dan senang bersembunyi di balik rasa ketidakpercayaan.

Penguatan efikasi diri pada pribadi introvert memerlukan konsep tafakur agar pribadi introvert dapat berinteraksi dengan baik di lingkungannya. Secara bahasa (morfologis), kata tafakuryang berinisial dari akar kata tafakkara, yatafakkaru, tafakkuran dengan kata dasar fakkara, seperti perkataan orang 
arab yang artinya: "telah memikir ia akan suatu". Menurut DR. Malik Badri dalam bukunya yang berjudul Al- Tafakkur min Musyahadah lla Syuhud,tafakur dapat ditinjau dari beberapa aspek, yaitu: dzikir, bersyukur, tobat, zuhud terhadap dunia,dan akhlakul karimah (Malik Badri, 1996: 8).

- Tafakur melalui Dzikir

Secara etimologi dzikir berasal dari kata "zakara" berarti menyebut, mensucikan, menggabungkan, menjaga, mengerti, mempelajari, memberi dan nasehat. Oleh karena itu dzikir berarti mensucikan dan mengagungkan, juga dapat diartikan menyebut dan mengucapkan nama Allah atau menjaga dalam ingatan (Hazri Adlany, 2002: 470).

Dzikir merupakan ibadah hati dan lisan yang tidak mengenal batasan waktu. Bahkan Allah menyifati ulil albab, adalah mereka-mereka yang senantiasa menyebut Rabnya, baik dalam keadaan berdiri, duduk, bahkan juga berbaring. Oleh karenanya dzikir bukan hanya ibadah yang bersifat lisaniyah, namun juga qalbiyah (Ismail Nawawi, 2008: 244).

- Tafakur melalui Bersyukur

Secara bahasa syukur adalah pujian kepada yang telah berbuat baik atas apa yang dilakukan kepadanya. Syukur adalah kebalikan dari kufur. Hakikat syukur adalah menampakkan nikmat, sedangkan hakikat kekufuran adalah menyembunyikannya (Muhammad Quraish Shihab, 1996: 216). Menurut istilah syara', syukur adalah pengakuan terhadap nikmat yang diberikan oleh Allah Swt dengan disertai ketundukan kepada-Nya dan mempergunakan nikmat tersebut sesuai dengan kehendak Allah Swt (Muhammad Syafi'ie elBantanie, 2009: 2).

- Tafaku rmelalui Akhlakul Karimah

Akhlak adalah suatu sifat yang tertanam dalam diri manusia dan bisa bernilai baik atau buruk. Akhlak tidak selalu identik dengan pengetahuan, ucapan ataupun perbuatan orang yang bisa mengetahui banyak tentang baik buruknya akhlak, tapi belum tentu ini didukung oleh keluhuran akhlak, orang 
bisa bertutur kata yang lembut dan manis, tetapi kata-kata bisa meluncur dari hati munafik. Dengan kata lain, akhlak merupakan sifat-sifat bawaan manusia sejak lahir yang tertanam dalam jiwanya dan selalu ada padanya. Al-Qur'an selalu menandaskan bahwa akhlak itu baik atau buruknya akan memantul pada diri sendiri sesuai dengan pembentukan dan pembinaannya (Sukanto, 1994: 80).

Tafakur dalam Islam menempati posisi sentral.Allah Swt menganjurkan manusia untuk bertafakur mengenai kitab suci AlQur'an serta fenomena alam semesta dan Allah memuji orangorang yang bertafakkur.Perintah tafakur dalam Islam, sebagaimana dasar-dasarnya yang telah dijelaskan di muka, mengandung pengertian bahwa aktifitas tafakur merupakan ibadah, karena melaksanakan ajaran agama karena ibadah.Ada beberapa hikmah tafakur, diantaranya yakni meningkatkan keimanan dan ibadah, mengasah kecerdasan, sebagai dasar pembelajaran, dan mempertajam kepekaan sosial.

Dalam proses meningkatkan efikasi diri pribadi introvert dengan bertafakur seseorang akan menghindari diri dari penyesuaian diri yang maladaptif dan sebaliknya dengan melakukan penyesuaian diri yang adaptif. Menurut Syamsu Yusuf, dalam proses melakukan penyesuaian diriyang dipandang mempunyai penyesuaian diri yang baik adalah seseorang yang telah belajar bereaksi terhadap dirinya dan lingkungannya dengan cara-cara yang matang, efisien, memuaskan dan sehat, serta dapat mengatasi konflik mental, frustasi, kesulitan pribadi dan sosial tanpa mengembangkan perilaku simptomatik dan gangguan psikomatik yang mengganggu tujuan-tujuan moral, sosial, agama dan pekerjaan. Orang seperti itu mampu menciptakan dan mengisi hubungan antarpribadi dan kebahagiaan timbal-balik yang mengandung realisasi dan perkembangan kepribadian secara terus-menerus (Syamsu Yusuf, 2004: 176). Dalam konsep Islam adalah dengan membangun akhlakul karimah terhadap sesama manusia dan terhadap Allah Swt. 
Dikatakan efisien artinya mampu melakukan respons dengan mengeluarkan tenaga dan waktu sehemat mungkin.Dikatakan sehat artinya bahwa respons-respons yang dilakukannya sesuai dengan hakikat individu, lembaga, atau kelompok antar individu, dan hubungan antar individu dengan penciptanya.Bahkan, dapat dikatakan bahwa sifat sehat ini adalah gambaran karakteristik yang paling menonjol untuk melihat atau menentukan bahwa suatu penyesuaian diri itu dikatakan baik (Mohammad Ali dan Mohammad Asrori, 2012: 176).

Dalam proses menafakkuri diri pribadi dan lingkungan yang membentuk perilaku memandang diri dan sosial secara positif maka diharapkan seseorang selalu memikirkan segala hal sebelum mewujudkannya dalam bentuk perbuatan agar semua yang dilakukan dapat mendatangkan manfaat baik bagi diri sendiri maupun orang lain. Sehingga individu tersebut akan mampu menjalankan tugas-tugas mereka dengan baik tanpa menimbulkan konflik dalam diri maupun lingkungannya.

Efikasi diri yang rendah berimplikasi pada kurangnya tafakur terhadap segala sesuatu yang dihadapi oleh individu sepanjang hidupnya. Dalam rentan kehidupan manusia tidak terlepas dari proses penyesuaian diri baik sejak didalam kandungan hingga berakhir pada kematian.

Pentingnya efikasi diri tinggi terutama pada individu introvert. Untuk itu, materi tafakur dalam konsep Islam hadir untuk mengarahkan individu kepada konsep Islami bahwa itu dapat memudahkan individu untuk melihat segala realitas kehidupannya optimis baik itu proses penyesuaian dirinya dengan lingkungan akan lebih baik lagi, karena tafakur itu adalah suatu kegiatan yang dilakukan oleh manusia untuk mempresentasikan dunia sebagai model dan memberikan perlakuan terhadapnya secara efektif sesuai dengan tujuan dan cara menghadapi suatu masalah dengan mengambil hikmah dibalik masalah yang dihadapi, sehingga tidak menimbulkan konflik atau pertentangan dalam dirinya yang pahami sebagai komunikasi intrapersonal dengan memahami dan memberikan solusi terhadap dirinya bahwa masih banyak 
kekurangan-kekurangan yang ada pada diri individu tersebut, sehingga materi tafakur akan sangat berguna untuk meningkatkan efikasi diri.

\section{KESIMPULAN}

Peningkatan diri dipengaruhi oleh efektivitas tafakur yang dirasakan subjek dan keberhasilan subjek dalam menginternalisasikan nilai-nilai berpikir positif yang dipetik setelah selesai pelatihan. Individu lebih berpikir positif, ada kemauan untuk mengerjakan segala sesuatunya dengan baik dan tepat waktu seperti tugas-tugas yang diberikan orang tua, guru,dosen, maupun tempat dimana dia tinggal, mampu mengawali hari-hari dengan penuh rasa percaya diri ketika sudah berada di lingkungan tempat individu beraktifitas, selalu berusaha untuk berpikir positif terhadap apapun serta memaknai segala halnya dengan penuh rasa optimis, mengendalikan emosi yang tidak baik, mudah tersenyum baik terhadap teman, dan ringan dalam mengerjakan segala bentuk kewajiban sebagai hamba Allah SWT. Alasan yang dapat mendasari adalah meningkatnya efikasi diri individu introvert dengan tafakur adalah usaha untuk menerima informasi dengan baik untuk dirinya sendiri dengan selalu berpikir positif terhadap segala hal. 


\section{DAFTAR PUSTAKA}

Adlany, H. 2002. Al-Qur'an Terjemah Indonesia. Jakarta: Sari Agung.

Ali, M. dan Asrori, M. 2012. Psikologi Perkembangan Peserta Didik. Jakarta: PT. Bumi Aksara.

Alwisol. 2012. Psikologi Kepribadian Edisi Revisi. Malang: UMM Press.

Badri, M. 1996. "Al- Tafakur min Musyahadah lla Syuhud" dalam Deddy Mulyana,Tafakur Perspektif Psikologi Islam. Bandung: PT. Remaja Rosdakarya.

Bandura, A. 1997. Self Efficacy: The Exercise of Control. United States: W. H. Freeman.

Baron, R.A. dkk. 1997. Psikologi Sosial jilid 1. Terj. Ratna Juwita. Jakarta: Erlangga.

Budiraharjo, P. 1997. Mengenal Teori Kepribadian Mutakhir, Yogyakarta: Kanisius.

Carlos, M. Z dan Nisfiannor, M. 2006. Hubungan Self Efficacy dan Prestasi Kerja Karyawan Marketing. Jakarta: Fakultas Psikologi Universitas Tarumanegara.

El-Bantanie, M. S. 2009. Dahsyatnya Syukur. Jakarta: Qultum Media.

Heerdjan, S. 1987. Apa itu Kesehatan Jiwa?. Jakarta: Fakultas Kedokteran Universitas Indonesia.

Keating, J.K. 1987. Bagaimana Menghadapi Orang Sulit. Yogyakarta: Kanisius.

Nawawi, I. 2008. Risalah Pembersih Jiwa: Terapi Perilaku Lahir dan Batin dalam Perspektif Tasawuf, Surabaya: Karya Agung Surabaya.

Ogden, J. 2008. Health Psykology: A Text Book. Buckingham: Open University Press.

Prayitno, S. H. "Hubungan antara Kepribadian Introvert dan Ekstrovert Dengan Speaking Skill Mahasiswa Prodi D III 
Keperawatan Tahun Akademik 2017/2018”, Vol. 14, No. 1, 2018.

Rachmawati, Y. 2005. Strategi Pengembangan Kreativitas pada Anak Usia Taman Kanak-Kanak. Jakarta: Depdikbud.

Shihab, M. Q. 1996. Wawasan Al-Qur'an: Tafsir Maudhu'i atas Pelbagai Persoalan Umat. Bandung: Mizan.

Smet, B. 1994. Psikologi Kesehatan. Jakarta:PT Grasindo.

Sujanto, dkk., 1984. Psikologi Kepribadian. Jakarta : Penerbit Aksara Baru, t.t.

Sukanto. 1994. Paket Moral Islam Menahan Nafsu dari Hawa. Solo: Maulana Offset.

Thursan. 2002. Mengatasi Rasa Tidak Percaya Diri. Jakarta: Erlangga.

Yusuf, S. 2004. Psikologi Perkembangan Anak dan Remaja. Bandung: PT. Remaja Rosdakarya. 